Received 27.11.2016 Reviewed 30.01 .2017 Accepted 04.05.2017

A - study design

B - data collection

C - statistical analysis

D - data interpretation

E - manuscript preparation

F - literature search

\section{Dynamic simulation for wastewater treatment plants management: Case of Souk-Ahras region, north-eastern Algeria}

\author{
Dairi SABRI ${ }^{1) \mathrm{ABD}}{ }^{凶}$, Djebbar YASSINE ${ }^{2) \mathrm{AD}}$, Hammar YAHIA ${ }^{1) \mathrm{EF}}$, \\ Mrad DOUNIA ${ }^{2) C}$
}

\footnotetext{
${ }^{1)}$ Badji Mokhtar Annaba University; Department of Hydraulic, P.O. Box 12, 23000 Annaba, Algeria; e-mail: daira_sabri@hotmail.fr,yachaze@yahoo.fr

${ }^{2)}$ Mohamed-Cherif Messaadia University - Souk-Ahras, InfraRes Laboratory, Souk Ahras, Algeria; e-mail: ydjebbar@gmail.fr, hydrorad@yahoo.fr
}

For citation: Sabri D., Yassine D., Yahia H., Dounia M. 2017. Dynamic simulation for wastewater treatment plants management: Case of Souk-Ahras Region, north-eastern Algeria. Journal of Water and Land Development. No. 34 p. 221-231. DOI: 10.1515/jwld-2017-0057.

\begin{abstract}
Treatment performances of two wastewater treatment plants (WWTPs), located in North-Eastern Algeria (Souk-Ahras and Sedrata) were tested using ASM1 model.

The model, to be considered as a decision tool for the appropriate management of activated sludge systems, served for the prediction of both WWTP behaviours under different operating conditions. In Sedrata WWTP the first management scenarios is based on an increase of inflow rate, taking into account a new transfer volume from a nearby zone. In a second scenerio, the ultimate flow of $40000 \mathrm{~m}^{3} \cdot \mathrm{d}^{-1}$ is estimated. Regarding Souk-Ahras WWTP, three scenarios were tested. The first tested the impact of an increase of the extraction flow rate and yielded a reduction by $37 \%$ of sludge production. The second dealt with the management of the mass budget of substrata and biomass. Finally, the third application was devoted to the estimation of the plant ultimate capacity, estimated to be $60000 \mathrm{~m}^{3} \cdot \mathrm{d}^{-1}$.
\end{abstract}

Key words: activated sludge, Algeria, ASM1, simulation, wastewater

\section{INTRODUCTION}

The process of activated sludge is one of the most wide-spread processes for wastewater treatment plants (WWTPs) of average to big population [JENKINS, WANNER (ed.) 2014].The activated sludge treatment process is composed of two mains entities. These are the reactor in the vicinity of which pollution is decomposed, especially via biological mechanisms and the clarifier, which separates treated water from the biomass and other particulate matter, essentially through physical processes [CHACHUAT et al. 2000]. However, activated sludge processes become complicated because of their changing physical characteristics and variability of the pollution load of raw wastewater [BARNETT et al. 1995]. This clearly demonstrates the need for modelling and simulations, not only to describe the different phases and processes involved in the treatment process but also to make predictions under different management scenarios [HAN, QIAO 2012].

Numerous applications and research activities, dealing with the modelling of biological degradation mechanisms in wastewater treatment plants were carried out over the last 20 years to acquire the knowledge on the management, the prediction and the control of the strategies of functioning in various conditions [JEPPSSON et al. 2013; VANROLLEGHEM et al. 2014].

In this context, the International Association of Water Quality (IAWQ) developed ASM1, ASM2 and 
more recently ASM3 models [GUJER et al. 1999; HENZE et al. 1987]. These are simple models which simulate the different processes of biological degradation within basins of activated sludge. The widespread application of these models showed their prediction capacities under different operating conditions [JEPPSON 1996].

Modelling contributions were also provided by French Research Institute for Agricultural and Environmental Engineering (Fr. Centre national du machinisme agricole du génie rural, des eaux et des forêts - CEMAGREF), dealing basically with: (i) the evaluation of maximum capacities of activated sludge basins with respect to nitrogen treatment and the optimization of their management under critical conditions [STRICKER 2000]; (ii) the comparison of simulation results to those obtained by conventional methods, such as biological oxygen demand and sludge production [CHOUBERT 2002; STRICKER 2000] and (iii) the determination of a set of standard parameters for activated sludge with extended aeration. SIEGRIST and TSCHUI [1992] modelled two WWTPs in Switzerland using the model ASM1 in order to optimize and predict their behaviour under different operating conditions. BAHGAT [2000] in SOROUR and BAHGAT [2004] developed an expert system called "activated sludge expert" to help inexperienced operators exploiting their activated sludge wastewater treatment plants. Strategies of control of the WWTPs were presented by ARAUJO et al. [2013]; HUANG and GOEL [2015] and NGUYEN et al. [2013] based on the optimal economic operation. Founded on the techniques of optimization of activated sludge processes, several recent studies were developed to examine a compromise between processing costs and final quality of uncluttered waters. GUERRERO et al. [2012] considered an additional objective function (office) in their problem of optimization to face the risk of profusion of muds. HAKANEN et al. [2011; 2013] used the approach of multiple-objective optimization to choose the most adequate strategy for the exploitation of large-size WWTPs.

In spite of these different research efforts, dealing with mathematical modelling of activated sludge processes, IAWQ models, especially ASM1, are the most known and most accepted, at the international level, by researchers and practicing managers. In this context, this study intends to develop control strategies for two WWTPs in north-eastern Algeria (Souk-Ahras and Sedrata) using the activated sludge model ASM1 via the simulator GPS-X based on the guidelines provided by the IWA Task Group on Good Modeling Practice [RIEGER et al. 2012] as a general framework for the simulation and the creation of the virtual platform of tests. This latter is used to: (i) determine the running conditions of both WWTPs as a function of their respective sizes and functioning states, (ii) examine the variability of organic matter content depending on raw water quality and (iii) predict the be- haviour of a biological reactor as a result of a variation of parameters or input data.

This paper first presents the configuration and the present operation system of both plants. Then, the software GPS-X used in the simulations and the theoretical background of the model ASM1 are briefly outlined. Following the model calibration and validation, simulations are performed for both plants to predict their respective behaviours under different predefined management scenarios. The obtained results are then discussed and compared.

\section{MATERIALS AND METHODS}

\section{CLIMATIC OVERVIEW OF SOUK-AHRAS REGION}

In the area of Souk-Ahras, rainfall annual average, unequally distributed in time and space, follows a gradient growing of the south $(250 \mathrm{~mm})$ towards north $(1000 \mathrm{~mm})$. The increase in rainfall in this part of the chain tellian is mainly related to the altimetric gradient. During the surplus years (water resource year 2002/2003 for example), the rainfall exceeds the $800 \mathrm{~mm}$ with Souk-Ahras and $700 \mathrm{~mm}$ with Sedrata. By reference to the station of Souk-Ahras, and the caused year, more than $90 \%$ of the rains fall between November and April, with a maximum recorded in the month January (300 mm).

In the Souk-Ahras region, the annual average temperature is about $15.4^{\circ} \mathrm{C}$. It spreads out between $7.4^{\circ} \mathrm{C}$ in January and $25.3^{\circ} \mathrm{C}$ in August. The minima are observed during wintry time (December-March) with an average of $4^{\circ} \mathrm{C}$. The annual average of the minima is about $10^{\circ} \mathrm{C}$. During the January, coldest, the thermometers record in averages $3.3^{\circ} \mathrm{C}$. During the dry period (June-September), the maximum ones record on average nearly $30^{\circ} \mathrm{C}$; the hottest month being August with $33^{\circ} \mathrm{C}$.

In the area of Souk-Ahras the strongest speeds of the wind are marked in autumn of direction $\left(74 \mathrm{~m} \cdot \mathrm{s}^{-1}\right.$ in October) are generally dry winds but this does not prevent them from being the cause of some storms especially when they change direction. In winter, the dominant direction of the winds is NW, they are not dry and cause intense rains although their speed is not very strong.

\section{PRESENTATION OF THE WWTPS}

Two wastewater treatment plants located in north-eastern Algeria are considered in this study. Their operating conditions are presented in Table 1. This table clearly shows that an important quantity of raw wastewater is disposed of directly in the environment, without any treatment while the WWTP is capable of treating the whole quantity of raw wastewater produced in the region. This is mainly explained by the failure of the existing sewer network to collect all of this raw water and direct it to the WWTPs. To avoid 
Table 1. Operating data of the wastewater treatment plants (WWTPs)

\begin{tabular}{|l|c|c|}
\hline \multirow{2}{*}{\multicolumn{1}{|c|}{ Parameter }} & \multicolumn{2}{c|}{ WWTP } \\
\cline { 2 - 3 } & Souk-Ahras & Sedrata \\
\hline Equivalent population & 150000 & 100000 \\
\hline Daily average flow rate, $\mathrm{m}^{3} \cdot \mathrm{d}^{-1}$ & 10000 & 4000 \\
\hline Sludge residence time, $\mathrm{d}$ & 20 & 20 \\
\hline BOD $_{5}$ load, $\mathrm{kg} \cdot \mathrm{d}^{-1}$ & 3315 & 1403 \\
\hline Plant capacity, $\mathrm{m}^{3} \cdot \mathrm{yr}^{-1}$ & 10950000 & 7300000 \\
\hline Raw wastewater volume in $2014, \mathrm{~m}^{3}$ & 2800000 & 1800000 \\
\hline Effluent volume in $2014, \mathrm{~m}^{3}$ & 2308119 & 1385869 \\
\hline
\end{tabular}

Source: own elaboration.

this overwhelming situation, six lift stations are scheduled to gather raw wastewater from the different zones of the region of Souk-Ahras, characterized by its mountainous nature and extremely varying altitudes. Furthermore, it is also expected to transfer wastewaters from a nearby community (M'Daourouch) to Sedrata WWTP.

The appropriate performances of both Souk-Ahras and Sedrata WWTPs face numerous problems. First, it is difficult to dispose of the ever increasing sludge quantities, especially because of the reluctance of farmers in using this wastewater treatment by product. Second, real characteristics of the WWTPs are unknown to managers, and therefore no information is provided with respect to its present or ultimate capacities. Finally, the mass budget within the WWTPs has to be efficiently managed in order to allow exploitation personnel to take the right decision for optimal management of the treatment process. These management considerations are essential steps for the optimization of the WWTPs operation systems and their associated exploitation costs.

\section{MODELING OF THE ACTIVATED SLUDGE PROCESS}

\section{Presentation of the software GPS-X}

The simulation software used in this study is GPS-X of the Canadian firm Hydromantis [Hydromantis... 2006]. This software, developed in 1988, is widely used all over the world by consulting companies and municipalities among others. Later, many improvements were introduced to the model based on new research findings in the field of wastewater treatment. The model incorporates different subroutines classified in a library. The simulation of the operation of a particular WWTP by GPS-X is considered as an important interactive management tool. Indeed, an operator may control his/her virtual WWTP in real time, while observing on the screen the effect of changing any of the operating parameters.

\section{The model ASM1}

ASM1 is presented in the form of a matrix or table, where treatment processes as well as their corre- sponding kinetic and stoichiometric parameters are classified. The variables are noted by the letters $\mathbf{S}$ for soluble and $\mathbf{X}$ for particulate, completed by indices $\mathbf{B}$ for biomass, $\mathbf{H}$ for heterotroph $\mathbf{A}$ for autotrophs, $\mathbf{N}$ for nitrogen, $\mathbf{S}$ for substrate, $\mathbf{O}$ for oxygen, $\mathbf{I}$ for inert, $\mathbf{D}$ for degradable and $\mathbf{P}$ for produced bacterial lyses. The variables considered are concentrations of organic pollutants or biomass, expressed in $\mathrm{mg} \mathrm{COD} \cdot \mathrm{dm}^{-3}$ for carbonated compounds and $\mathrm{mg} \mathrm{N} \cdot \mathrm{dm}^{-3}$ for nitrogen compounds.

The ASM models use matrix notation for the presentation of biokinetic models. This approach for heterotrophic growth in an aerobic environment. HENZE et al. [1999] summarized the matrix approach, the components (state variables) which are to be considered in the model and the transformation processes are defined by the indices $i$ and $j$ respectively. The stoichiometric coefficients are presented in the form of a matrix defined by $v_{i j}$. The process rate constants form a vector $p_{j}$. The matrix is often referred to as the Peterson matrix [PETERSEN 1965] and will be referred to as such throughout this research.

The stoichiometric matrix relates to a material balance in the vertical direction. A material balance can be written for each component $i$ (state variable) which may be affected by one or all of the processes $j$.

The observed transfer rate is the sum of the transformation rates from each process [GUJER, HENZE 1991]. The rate of production of each component (state variable) $i, r_{i}$, can be computed by

$$
r_{i}=\sum v_{j i} \rho_{j} \text { for all process } j
$$

The material balance equations shown in Figure 1 are used as input to a numerical solver which generates either static (based on a snapshot of the system) or dynamic (time dependent variation) results.

The model ASM1 has to be combined with a model describing the decantation process to yield realistic results [HENZE et al. 1987]. An example of such model is the one dimensional multi-layer model which characterizes sedimentation based on the theory of solid mass flux in the vertical direction [EKAMA et al. 1997]. The clarifier is sub-divided into a number of equidistant completely mixed layers. This approach formulates mass equilibriums in order to keep the total solid masses suspended in each layer.

The supplying layer receives wastewater currents from the biological part of a wastewater treatment plant. An ascending hydraulic flux is therefore observed above the supply layer (clarification zone). Another downward flux (thickening zone) is also observed. Sedimentation velocity is calculated by the double exponential velocity method proposed by TAKACS et al. [1991]:

$$
v_{s j}=\max \left\{0, \min \left[v_{0}^{\prime}, v_{0}\left(e^{-r_{h}\left(X_{j}-X_{\min }\right)}-e^{-r_{p}\left(X_{j}-X_{\min }\right)}\right)\right]\right\}
$$

where: $v_{s j}=$ the settling velocity in layer $j ; X_{j}=$ suspended solids concentration in layer $j ; X_{\min }=$ the minimum attainable suspended solids concentration; 


$$
\frac{d S_{S}}{d t}=-\frac{1}{Y_{H}}\left(\mu_{m, H} \frac{S_{S}}{K_{S}+S_{S}} X_{O H O}\right)
$$

Mass balance equation for particulate substrate:

$$
\frac{d X_{O H O}}{d t}=-\frac{1}{Y_{H}}\left(\mu_{m, H} \frac{S_{S}}{K_{S}+S_{S}} X_{O H O}\right)-b X_{O H O}
$$

Mass balance equation dissolved oxygen:

$$
\frac{d S_{O}}{d t}=-\frac{1-Y_{H}}{Y_{H}}\left(\mu_{m, H} \frac{S_{S}}{K_{S}+S_{S}} X_{O H O}\right)-b X_{O H O}
$$

Numerical solver

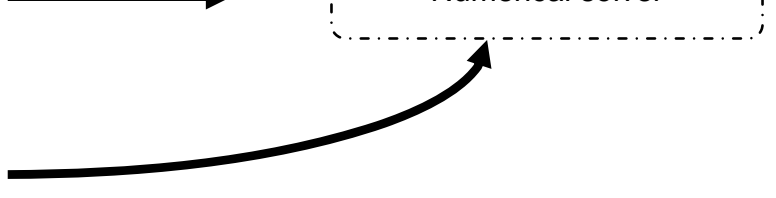

Fig. 1. Non steady state material balance equations for each state variable; source: own elaboration

$v_{0}^{\prime}, v_{0}=$ the maximum practical and theoretical settling velocities, respectively; $r_{h}, r_{p}=$ parameters characteristic of the hindered settling zone and the settling behaviour at low solids concentrations, respectively.

\section{RAW WASTEWATER CHARACTERISTICS}

Wastewater quality data observed over a period of 2 years (2013 to 2014) were used in the simulation exercise. The present functioning mode of the Souk-Ahras WWTP was characterized based on inquiries and long discussions with the plant managers about the incoming flow rates, recycling and extraction discharges, and the pollutant loads. Regarding Sedrata WWTP, the functioning process was followed via the automated board of the plant and water sampling campaigns. Raw wastewater characteristics of both plants are presented in Table 2.

Table 2. Raw wastewater characteristics

\begin{tabular}{|l|c|c|}
\hline \multicolumn{1}{|c|}{ Parameter } & Souk-Ahras WWTP & Sedrata WWTP \\
\hline Flow rate, $\mathrm{m}^{3} \cdot \mathrm{d}^{-1}$ & 10000 & 4000 \\
\hline$S_{S}, \mathrm{mg} \cdot \mathrm{dm}^{-3}$ & 500 & 560 \\
\hline $\mathrm{BOD}_{5}, \mathrm{mg} \cdot \mathrm{dm}^{-3}$ & 450 & 310 \\
\hline
\end{tabular}

Explanations: WWTP = wastewater treatment plants, $S_{S}=$ suspended solids.

Source: own elaboration.

\section{WASTEWATER TREATMENT PLANT CONFIGURATION AND OPERATING MODE}

Simulation of a WWTP operating system is based on the configuration of the treatment facility, the characterization of the management mode as well as the choice and the calibration of the adopted model. Each compartment of the WWTP is presented by a given model. In this study, the biological model ASM1and the one-dimensional sedimentation model of TAKACS [1991] were adopted. The selected control variables of both steps are: raw wastewater inflow, aeration system, dissolved oxygen, sludge recycling and extraction flow rates.

Figure 2 shows the present operation budgets of both Souk-Ahras and Sedrata WWTPs. The operation of Souk-Ahras WWTP was simulated by adjusting the parameters of proportionality between oxygen transfer in the sludge and clear water to approximately 0.9 .
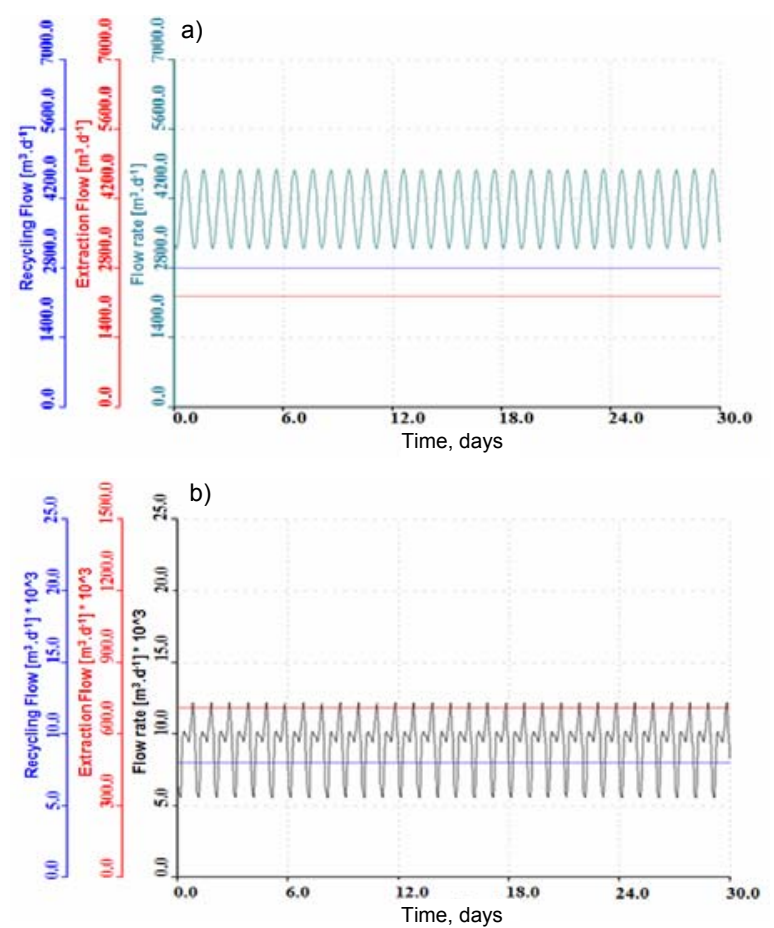

Fig. 2. The present operation budget: a) Sedrata wastewater treatment plant, b) Souk-Ahras wastewater treatment plant; source: own elaboration

Moreover, the concentration of dissolved oxygen in the reactor was fixed at a value of $2 \mathrm{mg} \cdot \mathrm{dm}^{-3}$.

These two adjustments resulted in a daily oxygen demand close to that calculated based on the WWTP design method. A fraction of recycled sludge is deviated toward the reactor $\left(13068 \mathrm{~m}^{3}\right)$ via two recycling pumps. A recycling rate of $8000 \mathrm{~m}^{3} \cdot \mathrm{d}^{-1}$ was selected in the steady state simulation in order to maintain the concentrations within the aeration basin close to measured values. An extraction discharge (730 $\mathrm{m}^{3} \cdot \mathrm{d}^{-1}$ ), reflecting the present operating mode of the WWTP, is selected. Simulations for Sedrata WWTP were performed based on an adjustment of the aeration parameters of an air diffuser system to a unit discharge of $10 \mathrm{~nm}^{3} \cdot \mathrm{h}^{-1}$. Recycling and extraction flow rates of $2800 \mathrm{~m}^{3} \cdot \mathrm{d}^{-1}$ and $225 \mathrm{~m}^{3} \cdot \mathrm{d}^{-1}$ respectively were adopted based on the present operation mode. It is important to note at this stage that an appropriate mass budget shall be attributed to the system to ensure an optimal activated sludge operation. 


\section{RESULTS AND DISCUSSION}

\section{MODEL CALIBRATION AND VALIDATION}

The dynamic modelling of the process of activated sludge became an essential tool for the design and the management of WWTPs [ELSHORBAGY, SHAWAQFAH 2015; INSEL et al. 2012]. However, the calibration of these models seems to be a critical point in their wide-spread application [SIN, VANROLLEGHEM 2007]. The choice of the relevant parameters required to make a reasonably good prediction is one of the major problems of activated sludge models (ASMs), encountered during both calibration and application phases [LIWARSKA-BIZUKOIC, BIERNACKI 2010].

Initial conditions were determined based on calibration for a steady state operation [PETERSEN 2000]. The obtained initial estimates are later introduced into dynamic simulation. The system is considered to be at equilibrium, where each output represents a state which is different of its processor and its successor. The adjusted parameters are introduced manually, taking into consideration their different interactions according to the following two principles: (i) a parameter is adjusted during the phase where the relative process is clearly dominant and (ii) biomass efficiencies are assumed to be correct in adjusting the decay kinetics. These parameters are usually estimated by means of respirometric tests [ELSHORBAGY, SHAWAQFAH 2015; KATIPOGLU-YAZAN et al. 2015]. Indeed, the rate of breath is directly related to two important biochemical processes which must be controlled in a WWTP: growth of biomass and substrate consumption [SPANJERS et al. 1996].

Values of certain biological parameters in the model ASM1 were modified. The growth rate of aerobic heterotroph bacteria, generally varying between 3 and $13.2 \cdot \mathrm{d}^{-1}$ [HENZE et al. 1987], was fixed at a value of $7 \cdot \mathrm{d}^{-1}$ while the coefficient of semi-saturation was fixed at $5 \mathrm{~g} \mathrm{COD} \cdot \mathrm{m}^{-3}$. The growth rate of the optimal aerobic heterotroph biomass presents a low value of $4 \cdot d^{-1}$.

The choice of the output variables depends on the fixed objective. Suspended solids concentration $(S)$ and COD in the aeration basin reflect the treatment quality. The mixed liquor concentration within the aeration biomass $(X)$ reflects its activity. The evolutions of these two state variables $(S$ and $X)$ are followed in calibration. Three different types of calibration parameters in the software GPS-X are distinguished. These are parameters related to fractioning of organic matter, stoichiometric parameters and kinetic parameters. Calibration may be performed manually or based on optimization techniques [HENZE et al. 1987]. In this study, we opted for the parameters related to organic matter fractioning COD, which are grouped in Table 3. However, the optimization module 'optimizer' of the GPS-X software was used to determine kinetic and stoichiometric parameters $\left(Y_{H}-\right.$ heterotrophic yield coefficient, $\mu_{H}$ - maximum hetero- trophic growth rate, $b_{H}$ - decay coefficient, and $K_{s}-$ half saturation coefficient). The calibration parameters are presented in Table 4.

Table 3. Parameters related to organic matter fractioning COD

\begin{tabular}{|l|c|}
\hline \multicolumn{1}{|c|}{ Parameter } & Percentage \\
\hline Soluble inert substrate $S_{I}$ & $16 \%$ \\
\hline Readily biodegradable substrate $S_{S}$ & $25 \%$ \\
\hline Slowly biodegradable substrate $X_{S}$ & $37 \%$ \\
\hline Particulate inert substrate $X_{I}$ & $22 \%$ \\
\hline
\end{tabular}

Source: own study.

Table 4. Values of kinetic and stoichiometric parameters of wastewater treatment plants after calibration

\begin{tabular}{|l|c|c|}
\hline \multicolumn{1}{|c|}{ Parameter } & $\begin{array}{c}\text { Souk- } \\
\text {-Ahras } \\
\text { WWTP }\end{array}$ & $\begin{array}{c}\text { Sedrata } \\
\text { WWTP }\end{array}$ \\
\hline Maximum heterotrophic growth rate $\mu_{H}, \mathrm{~d}^{-1}$ & 1.7 & 7.5 \\
\hline Half saturation coefficient $K_{s}, \mathrm{~g}$ COD $\mathrm{m}^{-3}$ & 5 & 6 \\
\hline Heterotrophic yield coefficient $Y_{H}, \mathrm{~g}$ COD/g COD & 0.42 & 0.66 \\
\hline Decay coefficient $b_{H}, \mathrm{~d}^{-1}$ & 0.62 & 1.2 \\
\hline
\end{tabular}

Source: own study.

Figures 3 and 4 show the simulation results of the parameters $\mathrm{COD}$, BOD, following manual calibration over a period of 29 days. The relatively good agreement between simulated and measured values proves the model ability in simulating the organic matter decay by the activated sludge unit.
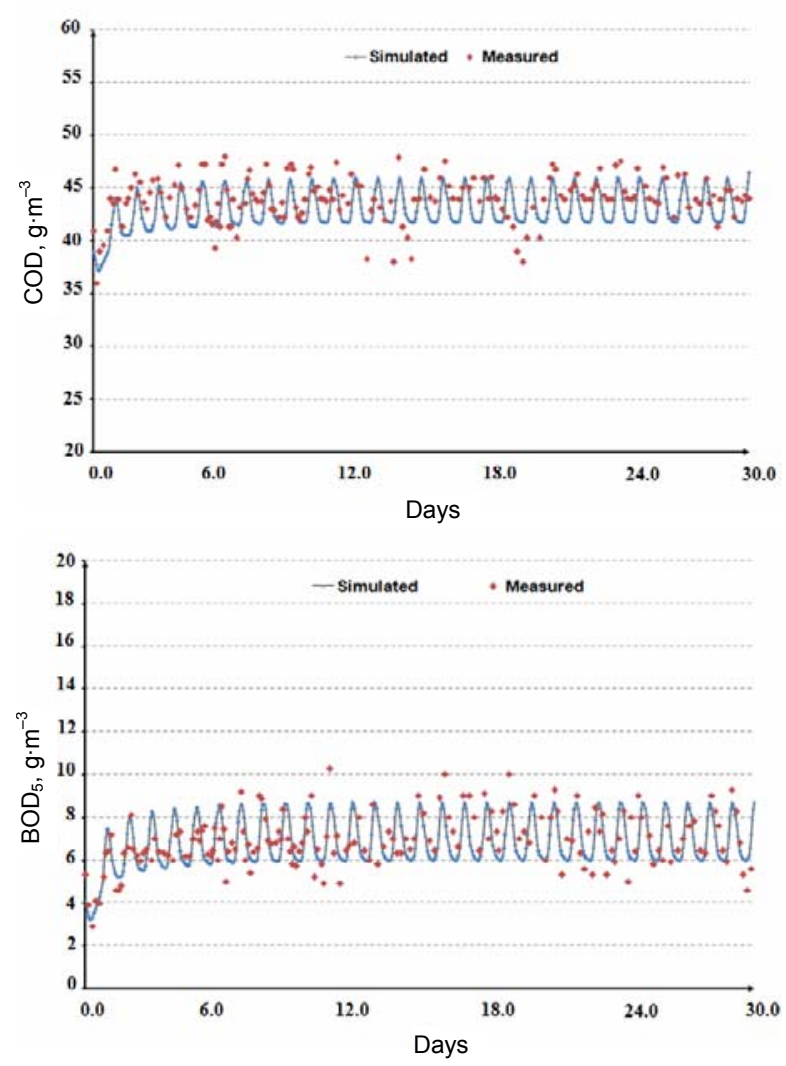

Fig. 3. Calibration results for the effluent $\mathrm{COD}$ and $\mathrm{BOD}_{5}-$ Souk-Ahras wastewater treatment plant; source: own study 

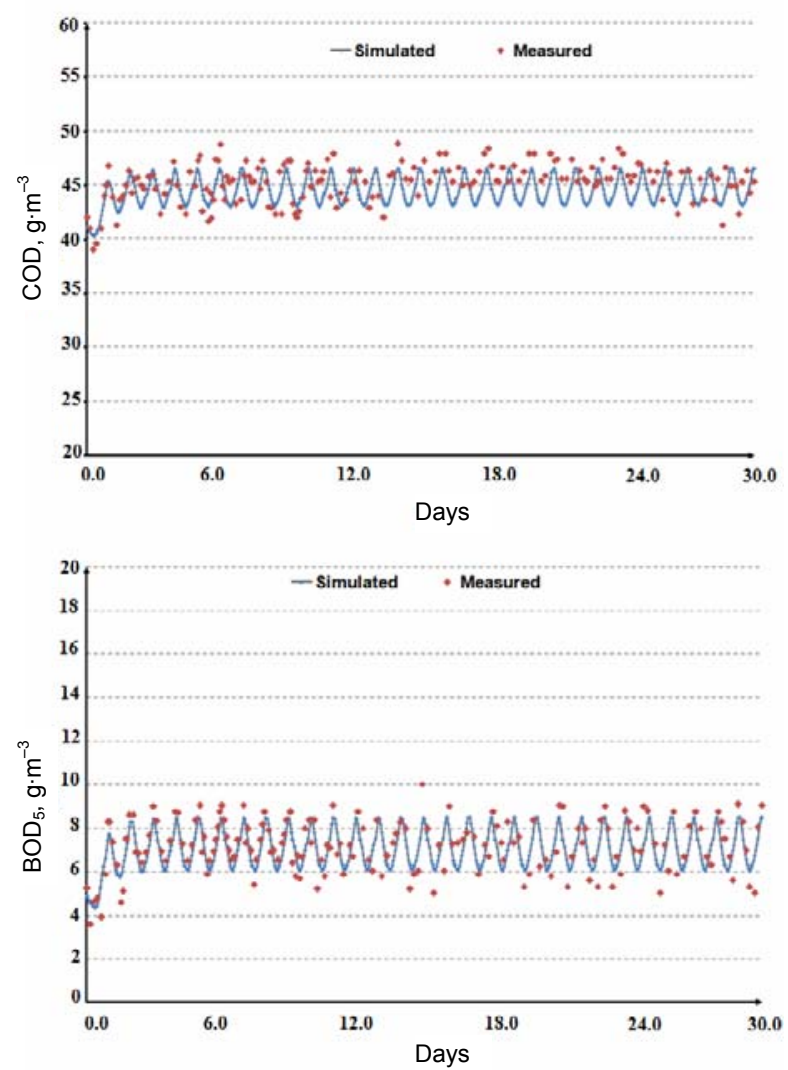

Fig. 4. Calibration results for the effluent $\mathrm{COD}$ and $\mathrm{BOD}_{5}-$ Sedrata wastewater treatment plant; source: own study

Following the model calibration, the model is validated for a dynamic state condition using other data series corresponding to a wet weather flow. Table 5 represents the results of the corresponding simulation.

Table 5. Input values for a 'wet weather flow' condition

\begin{tabular}{|l|c|c|}
\hline \multicolumn{1}{|c|}{ Parameter } & Souk-Ahras WWTP & Sedrata WWTP \\
\hline $\mathrm{COD}, \mathrm{mg} \cdot \mathrm{dm}^{-3}$ & 350 & 290 \\
\hline$S_{S}, \mathrm{mg} \cdot \mathrm{dm}^{-3}$ & 600 & 750 \\
\hline BOD, $\mathrm{mg} \cdot \mathrm{dm}^{-3}$ & 250 & 280 \\
\hline
\end{tabular}

Explanations: WWTP $=$ wastewater treatment plants, $S_{S}=$ suspended solids.

Source: own study.

Model validation should be based not only on visual inspection of the agreement between observed and simulated values, but also on statistical methods capable of testing this agreement. The root mean square error ( $R M S E$ ) (eq. 3) was used in this study to validate the model and confirm its reliability in reflecting the reality [POWER 1993].

$$
\frac{R M S E}{\bar{y}}=\frac{\sqrt{\frac{\sum(y-\hat{y})^{2}}{n}}}{\bar{y}}
$$

where: $y, \hat{y}=$ the observed and simulated values respectively; $y=$ the average of all observations $n$.

Table 6 displays RMSE values for both calibration and validation phases of the different output variables tested $\left(S_{S}\right.$, BOD, and COD) under dry weather and wet weather flow conditions. The results obtained confirm the reasonably good agreement, shown earlier by visual inspection.

Table 6. Statistical characteristics of the different output parameters of wastewater treatment plants (WWTPs)

\begin{tabular}{|c|c|c|c|c|c|c|c|c|c|c|c|c|}
\hline \multirow{3}{*}{ Parameter } & \multicolumn{6}{|c|}{ Souk-Ahras WWTP } & \multicolumn{6}{|c|}{ Sedrata WWTP } \\
\hline & \multicolumn{3}{|c|}{$\begin{array}{c}\text { calibration } \\
\text { (dry weather) }\end{array}$} & \multicolumn{3}{|c|}{$\begin{array}{c}\text { validation } \\
\text { (wet weather) }\end{array}$} & \multicolumn{3}{|c|}{$\begin{array}{l}\text { calibration } \\
\text { (dry weather) }\end{array}$} & \multicolumn{3}{|c|}{$\begin{array}{c}\text { validation } \\
\text { (wet weather) }\end{array}$} \\
\hline & $S_{S}$ & BOD & COD & $S_{S}$ & BOD & COD & $S_{S}$ & BOD & COD & $S_{S}$ & BOD & COD \\
\hline$R M S E / y$ & 0.19 & 0.20 & 0.08 & 0.26 & 0.27 & 0.11 & 0.21 & 0.10 & 0.07 & 0.3 & 0.21 & 0.16 \\
\hline
\end{tabular}

Explanations: $R M S E=$ root-mean-square error, $S_{S}=$ suspended solids. Source: own study.

\section{OPTIMIZATION OF THE OPERATION OF THE WWTPS}

Optimization of the unit functioning process involves the proposition of different operation methods of the biological system and then the selection of the procedure with best performance based on pre-defined criteria. In this context, several simulation scenarios are treated using GPS-X, where optimization of the WWTPs biological treatment is shown to be important to predict systematic approaches related to different operating conditions.

\section{Sedrata WWTP}

Two management scenarios for Sedrata WWTP were tested. The first is based on an increase of the raw wastewater inflow rate, taking into account the wastewater transfer volume from the locality of M'Daourouch. In a second step, the ultimate capacity of the WWTP and its saturation horizon are determined.

Transfer of wastewater from M'Daourouch to Sedrata WWTP. The objective is to determine the WWTP optimum operating conditions to cope with the new inflow rate. This latter is expected to increase from 4000 to $12000 \mathrm{~m}^{3} \cdot \mathrm{d}^{-1}$ because of the transfer from M'Daourouch Community. Simulation was performed based on the appropriate mass budget for this particular scenario, which resulted in optimal recycling and extraction rates of $9200 \mathrm{~m}^{3} \cdot \mathrm{d}^{-1}$ and 950 $\mathrm{m}^{3} \cdot \mathrm{d}^{-1}$ respectively. The corresponding results are shown in Figure 5 for flow rates, COD, BOD and suspended solid fraction. Average BOD and COD values at the clarifier outlet were simulated to be 16 and $66 \mathrm{mg} \cdot \mathrm{dm}^{-3}$ respectively. The undertaken simula- 

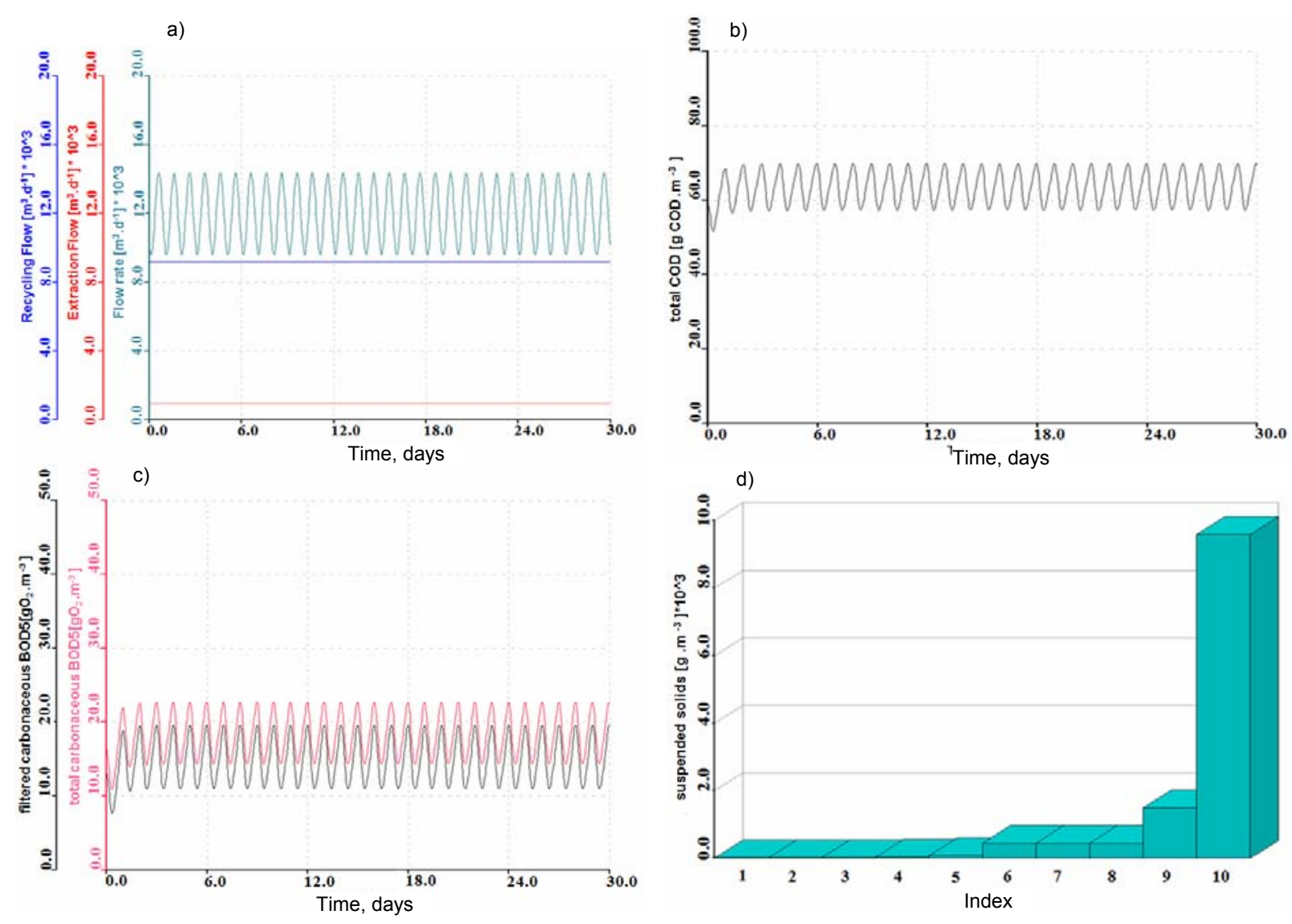

Fig. 5. Simulation results of the transfer of wastewater from M'Daourouch to Sedrata wastewater treatment plant: a) the appropriate mass budget, b) $\left(\mathrm{COD} \mathrm{g} \cdot \mathrm{m}^{-3}\right)$ concentration output, c) (BOD $\left.\mathrm{g} \cdot \mathrm{m}^{-3}\right)$ concentration output, d) suspended solid fraction in the clarifier; source: own study

tion confirms the possibility of transferring M'Daourouch wastewaters to Sedrata WWTP. However, the ultimate capacities of the recirculation and extraction pumps have to be checked.

Ultimate capacity of Sedrata WWTP. The following simulation intends to estimate the ultimate capacity of Sedrata WWTP, taking into account the wastewater transfer from M'Daourouch Locality. Optimization of the WWTP performance yielded an ultimate capacity of $40000 \mathrm{~m}^{3} \cdot \mathrm{d}^{-1}$, which largely exceeds the plant nominal capacity $\left(24000 \mathrm{~m}^{3} \cdot \mathrm{d}^{-1}\right)$ given in the exploitation guide. This would imply that Sedrata WWTP is capable to handle an extra transfer volume of $16000 \mathrm{~m}^{3} \cdot \mathrm{d}^{-1}$, which corresponds to the horizon 2033. Figure 6 shows the ultimate capacity of Sedrata WWTP, estimated to be around $40000 \mathrm{~m}^{3} \cdot \mathrm{d}^{-1}$, where a biological mal functioning starts.

\section{Souk-Ahras WWTP}

Three simulation scenarios were considered for Souk-Ahras WWTP. The first examines the possibility of a reduction of the produced sludge quantities. The second is interested in the management of the mass budget of substrate and biomass. Finally, the third scenario is devoted to the estimation of the plant ultimate capacity.

Sludge production management. The control of sludge production is a key element for the manage-

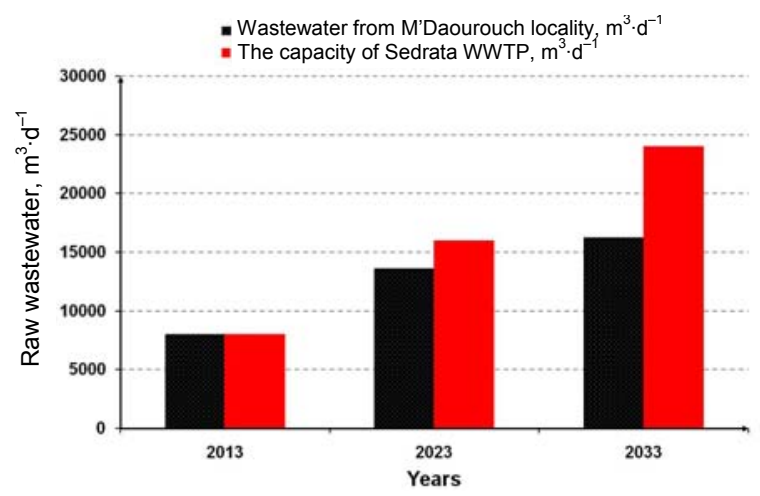

Fig. 6. The ultimate capacity of Sedrata wastewater treatment plant to the horizon 2033; source: own study

ment of the process. On one hand, the Increase of sludge quantity resulted in a serious interest, leading to more recovery of energy in biogas through the anaerobic digestion [GE et al. 2013]. On the other hand, their production in excess remains a delicate problem for the process, implying the need for the development of a process which controls these big masses [HuANG, GOEL 2015]. The effect of an increase of the extraction flow rate in the mass budget, with respect to a reference discharge in the model, is first examined. Figure 7 shows a reduction of $37 \%$ of sludge production when the extraction flow rate is increased from 710 to $900 \mathrm{~m}^{3} \cdot \mathrm{d}^{-1}$. Sludge extraction in an acti- 


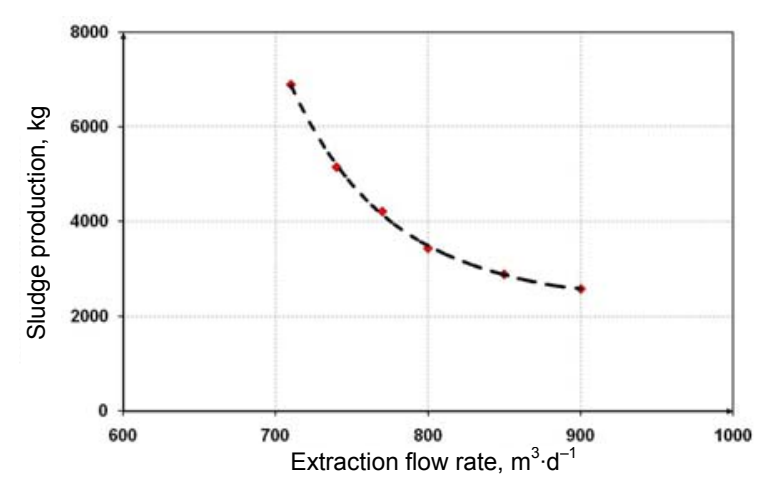

Fig. 7. Variation of sludge production with extraction flow rate; source: own study

vated sludge process allows the regulation of the residence time (sludge age) and thereby the regeneration rate of microorganisms. Thus, increasing extraction rates would result in non-developed sludge, with low production rate.

Effect of the extraction rate on the plant operating performances. The stability of the plant biological system is tested based on a variation of the extraction flow rate. Figure 8 shows the temporal variation of the pollution parameters $\left(\mathrm{BOD}, \mathrm{COD}, S_{S}\right)$ at the clarifier outlet for an extraction discharge of $700 \mathrm{~m}^{3} \cdot \mathrm{d}^{-1}$. Saturation of the clarifier was reached in day 5, when all examined parameters go beyond accepted standards, implying a malfunctioning of the biological system.

Ultimate capacity of Souk-Ahras WWTP. The ultimate capacity of the clarifier is obtained based on an estimation of the thickening surface, which represents the key element in clarifier design. Taking into account the initial concentration of the sludge layer (C0) and the simulated concentration at the bottom of the basin, clarification surfaces for different operating flow rates are determined. The designer may be faced with this type of analysis while designing clarifiers. Modelling is used to test different exploitation and design setups in order to determine the most appropriate operating conditions under different scenarios.

Table 7 displays thickening and clarification surfaces for different discharges. The design presented in the WWTP exploitation guide was shown to correspond to a daily flow rate of $30000 \mathrm{~m}^{3} \cdot \mathrm{d}^{-1}$, which confirms the clarifier ultimate capacity for each unit in the WWTP.

Table 7. Optimization of the clarifier ultimate capacity

\begin{tabular}{|c|c|c|}
\hline $\begin{array}{c}\text { Discharge } \\
\mathrm{m}^{3} \cdot \mathrm{d}^{-1}\end{array}$ & $\begin{array}{c}\text { Thickening surface } \\
\mathrm{m}^{2}\end{array}$ & $\begin{array}{c}\text { Clarification surface } \\
\mathrm{m}^{2}\end{array}$ \\
\hline 10000 & 520.83 & 250.25 \\
\hline 15000 & 781.25 & 375.37 \\
\hline 20000 & 1041.66 & 500.50 \\
\hline 25000 & 1302.08 & 625.62 \\
\hline 30000 & 1562.50 & 750.75 \\
\hline
\end{tabular}

Source: own study.
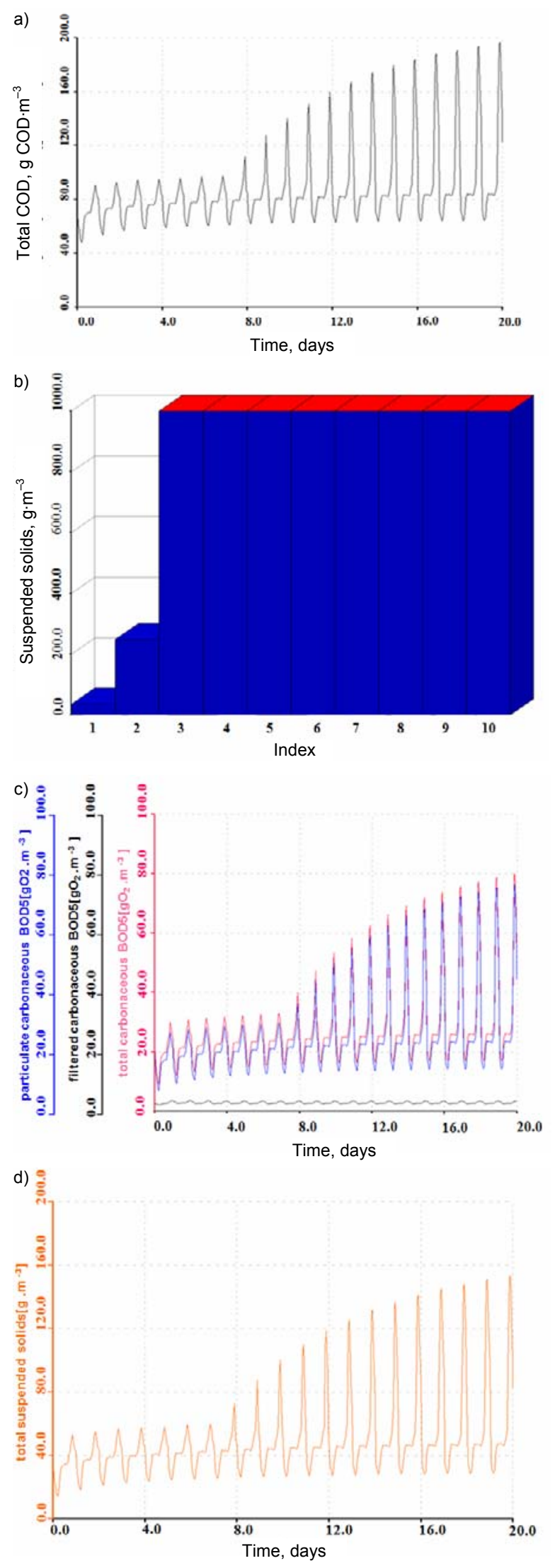

Fig. 8. Effect of the extraction rate on the plant operating performances: a) $\left(\mathrm{COD} \mathrm{g} \cdot \mathrm{m}^{-3}\right)$ concentration output,

b) suspended solid fraction in the clarifier, c) (BOD $\mathrm{g} \cdot \mathrm{m}^{-3}$ ) concentration output, d) (total $S_{S} \mathrm{~g} \cdot \mathrm{m}^{-3}$ ) concentration output; source: own study 


\section{CONCLUSIONS}

The simulations of the performances of Sedrata and Souk-Ahras wastewater treatment plants using GPS-X model under different scenarios are regarded as systematic approaches and decision tools for the appropriate management of both plants. The model was calibrated and then validated using two different data sets. A reasonably good agreement between observed and simulated quantity and quality parameters was achieved.

Sedrata WWTP was shown to be able to handle the wastewater volumes to be transferred from M'Darouch locality, but after checking the capacities of both recirculation and extraction pumps. The ultimate capacity of Sedrata WWTP was found to be $40000 \mathrm{~m}^{3} \cdot \mathrm{d}^{-1}$, exceeding by far the expected discharge of $12000 \mathrm{~m}^{3} \cdot \mathrm{d}^{-1}$. A reduction by $37 \%$ of sludge production in Souk-Ahras WWTP was achieved, when the extraction discharge was increased from 710 to $900 \mathrm{~m}^{3} \cdot \mathrm{d}^{-1}$. The ultimate capacity of Souk-Ahras WWTP was shown to be $60000 \mathrm{~m}^{3} \cdot \mathrm{d}^{-1}$, which largely exceeds the present inflow rate of only $10000 \mathrm{~m}^{3} \cdot \mathrm{d}^{-1}$.

All of the obtained results clearly show the importance of the tested model in predicting a WWTP behaviour under different scenarios and operating conditions. It may be regarded as an important decision tool, which may be used for the appropriate management of activated sludge systems.

It concludes that in this study, researchers and local technicians intervened to answer the following questions:

- What are the modelling tools that can be used to estimate the impacts of the local treatment policies?

- What are the interactions between various policies occurring at the local level (transfer, cost, planning, etc.)?

- How can they be estimated?

- Are these tools easily adoptable by local authorities?

- What dialogue to establish between modellers and communities for a better appropriation of decisionmaking tools?

The perspectives of the work include the following axes:

- The reduction of the energy consumption of the WWTP with mud activated based on:

- the control of the dissolved oxygen and its variation in the biological reactor;

- the control of the operating cycle of surface ventilators to optimize the functioning and stop periods corresponding to a normalized treatment system.

- The use of the tools of computational fluid dynamics (CFD) to estimate various sorts of control of the performance system.

\section{Acknowledgement}

We are indebted to the members of the Souk-Ahras and Sedrata WWTP, who supplied the necessary data to realize the work. We are also grateful to the members of the hydraulic team of the research laboratory InfraRes of the University of Souk-Ahras, Algeria.

\section{REFERENCES}

Araujo A.C., Gallani S., Mulas M., Skogestad S. 2013. Sensitivity analysis of optimal operation of an activated sludge process model for economic controlled variable selection. Industrial and Engineering Chemistry Research. Vol. 52. Iss. 29 p. 9908-9921.

BAHGAT L.M. 2000. A knowledge-based decision support system for an activated sludge wastewater treatment plant. MSc thesis. Department of Information Technology, Institute of Graduate Studies and Research, Alexandria University, Egypt pp. 186.

Barnett M.W., Takacs I., Stephenson J., Gall B., PerDEUS M. 1995. Dynamic modeling: New simulation tools provide insight into waste-water treatment plant design and operations. Water Environment and Technology. Vol. 7. Iss. 12 p. 41-44.

Chachuat B., Roche N., Latifi M.A. 2000. Identification et optimisation dynamique d'une station d'épuration de petite taille [Identification and dynamic optimization of a small-sized WWTP]. Report concerning the collaboration on the technical exchanges in modeling of WWTP. Paris, France. Vivendi Water pp. 144.

Choubert J.M. 2002. Analyse et optimisation du traitement de l'azote par des boues activées à basse température [Analysis and optimization of the treatment of the nitrogen by low-temperature activated sludge]. PhD thesis in Process engineering. Strasbourg, France University of Strasbourg pp. 265.

Ekama G.A., Barnard J.L. Guenthert F.W., Krebs P., McCorquodale J.A., Parker D.S., Wahlberg E.J. 1997. Secondary settling tanks: Theory, modeling, design and operation. Scientific and Technical Report. No. 6. International Association on Water Quality. London p. 187-203.

Elshorbagy W.E., Shawaqfah M. 2015. Development of an ASM1 dynamic simulation model for an activated sludge process in United Arab Emirates. Desalination and Water Treatment. Vol. 54. Iss. 1 p. 15-27.

Ge H., Batstone D.J., Keller J. 2013. Operating aerobic wastewater treatment at very short sludge ages enables treatment and energy recovery through anaerobic sludge digestion. Water Research. Vol. 47. Iss. 17 p. 65466557.

Guerrero J., Guisasola A., Comas J., Rodríguez-Roda I., BAEZA J.A. 2012. Multi-criteria selection of optimum WWTP control set points based on microbiology-related failures, effluent quality and operating costs. Chemical Engineering Journal. Vol. 188 p. 23-29.

Gujer W., HenZE M. 1991. Activated sludge modelling and simulation. Proceedings of the 15th Biennial Conference of the International Association on Water Pollution Research and Control. July 29, 1990 - August 3, 1990, Kyoto, Japan p. 1011-1023.

Gujer W., Henze M., Mino T., Van Loosdrecht M. 1999. Activated sludge model no. 3. Water Science and Technology. Vol. 39. Iss. 1 p. 183-193.

Hakanen J., Miettinen K., SAhlstedt K. 2011. Wastewater treatment: New insight provided by interactive 
multi objective optimization. Decision Support Systems. Vol. 51. Iss. 2 p. 328-337.

Hakanen J., Sahlstedt K., Miettinen K. 2013. Wastewater treatment plant design and operation under multiple conflicting objective functions. Environmental Modelling and Software. Vol. 46 p. 240-249.

HAN H.G., QIAO J.F. 2012. Prediction of activated sludge bulking based on a self-organizing RBF neural network. Journal of Process Control. Vol. 22. Iss. 6 p. 11031112.

Henze M., Grady Jr C.P.L., Gujer W., Marais G.V.R., MATSUO T. 1987. Activated sludge model no. 1: IAWPRC Scientific and Technical Report No. 1. IAWPRC, London.

Henze M., Gujer W., Mino T., Matsuo T., Wentzel M.C., vR MARAIS G., VAN LOOSDRECHT M.C. 1999. Activated sludge model no. 2d, ASM2d. Water Science and Technology. Vol. 39. Iss. 1 p. 165-182.

Henze M., Gujer W., Mino T., VAn LoOsdrecht M.C.M. 2000. Activated sludge models ASM1, ASM2, ASM2d and ASM3. IWA publishing.

HuANG P., GoEL R. 2015. Response of a sludge-minimizing lab-scale BNR reactor when the operation is changed to real primary effluent from synthetic wastewater. Water Research. Vol. 81 p. 301-310.

Hydromantis, Inc. 2006. GPS-X 5.0 - User's guide and Technical Reference. Hamilton, Ontario (Canada).

InSEl G., GÜDER B., GÜNEŞ G., UBAYCOKGOR E. 2012. Are standard wastewater treatment plant design methods suitable for any municipal wastewater? Water Science and Technology. Vol. 66. Iss. 2 p. 328-335.

Jenkins D., WANNER J. (ed.) 2014. Activated sludge - 100 years and counting. London. IWA Publ. ISBN 9781780404943 pp. 464.

JEPPSSON U. 1996. Modeling aspects of wastewater treatment processes. PhD thesis. Department of Industrial Electrical Engineering and Automation, Lund Institute of Technology, Sweden pp. 189.

Jeppsson U., Alex J., Batstone D. J., Benedetti L., Comas J., Copp J.B., Corominas L., Flores-Alsina X., Gernaey K.V., Nopens I., Pons M.N., Rodríguez-Roda I., Rosen C., Steyer J.P., Vanrolleghem P.A., VolcKe E.I., VRECKO D. 2013. Benchmark simulation models, quo vadis? Water Science and Technology. Vol. 68. Iss. 1 p. 1-15.

Katipoglu-YaZan T., UbayCoKgOR E., ORHON D. 2015. Modeling sequential ammonia oxidation kinetics in enriched nitrifying microbial culture. Journal of Chemical Technology and Biotechnology. Vol. 90. Iss. 1 p. 72 79.

LiWARSKA-BIZUKOJC E., BIERNACKI R. 2010. Identification of the most sensitive parameters in the activated sludge model implemented in BioWin software. Bioresource Technology. Vol. 101. Iss. 19 p. 7278-7285.
Nguyen D.H., Latifi M.A., Lesage F., Mulholland M. 2013. Dynamic simulation and optimization of wastewater treatment plants. International Conference on Process Control, PC. 18-21 June 2013. Štrbské Pleso, Slovakia p. 407-414.

Petersen B. 2000. Calibration, identifiability and optimal experimental design of activated sludge models. PhD. Thesis. Ghent University, Belgium pp. 252.

PETERSEN E.E. 1965. Chemical reaction analysis. Upper Saddle River, New Jersey. Prentice Hall pp. 276.

POWER M. 1993. The predictive validation of ecological and environmental models. Ecological Modelling. Vol. 68. Iss. 1 p. $33-50$.

Rieger L., Gillot S., Langergraber G., Ohtsuki T., Shaw A., TAK I., WinkLeR S. 2012. Guidelines for using activated sludge models. London. IWA Publ. ISBN 9781780401164 pp. 312.

SIEGRIST H., TSCHUI M. 1992. Interpretation of experimental data with regard to the activated sludge model no. 1 and calibration of the model for municipal wastewater treatment plants. Water Science and Technology. Vol. 25. Iss. 6 p. $167-183$.

Sin G., VANROLleghem P.A. 2007. Extensions to modeling aerobic carbon degradation using combined respirometric-titrimetric measurements in view of activated sludge model calibration. Water Research. Vol. 41. Iss. 15 p. 3345-3358.

Sorour M.T., BAHGAT L.M. 2004. Application of activated sludge models in traditionally operated treatment plants - a software environment overview. Water Quality Research Journal of Canada. Vol. 39. Iss. 3 p. 294-302.

Spanjers H., Vanrolleghem P., Olsson G., Doldt P. 1996. Respirometry in control of the activated sludge process. Water Science and Technology. Vol. 34. Iss. 3 p. $117-126$.

STRICKER A. 2000. Application of modeling to study nitrogen removal in the activated sludge process operated at very low F/M ratio: A comparison of dry and wet weather performance. $\mathrm{PhD}$ thesis in Process engineering. Strasbourg, France. University of Strasbourg pp. 308.

TAKÁCS I., Patry G.G., Nolasco D. 1991. A dynamic model of the clarification-thickening process. Water Research. Vol. 25. Iss. 10 p. 1263-1271.

Vanrolleghem P., Flores-Alsina X., Guo L., Solon K., IkUMi D., BAtstone D., JePpSSON U. 2014. Towards BSM2-GPS-X: A plant-wide benchmark simulation model not only for carbon and nitrogen, but also for greenhouse gases $(\mathrm{G})$, phosphorus $(\mathrm{P})$, sulphur $(\mathrm{S})$ and micropollutants $(\mathrm{X})$, all within the fence of WWTPs/ WRRFs. Proceedings 4th IWA/WEF Wastewater Treatment Modelling Seminar (WWTmod2014). 30.0302.04.2014. Spa, Belgium p. 123-128. 


\section{Dairi SABRI, Djebbar YASSINE, Hammar YAHIA, Mrad DOUNIA}

Dynamiczna symulacja zarządzania oczyszczalniami ścieków: przykład regionu Souk-Ahras w północno-wschodniej Algierii

\section{STRESZCZENIE}

Stosując model ASM1, testowano działanie dwóch oczyszczalni ścieków zlokalizowanych w północnowschodniej Algierii w miejscowościach Souk-Ahras i Sedrata. Model, traktowany jako narzędzie w podejmowaniu decyzji co do właściwego zarządzania systemem osadu czynnego, służył przewidywaniu zachowania się obu oczyszczalni w różnych warunkach operacyjnych. W oczyszczalni Sedrata w pierwszym scenariuszu zarządzania założono zwiększoną prędkość przepływu uwzględniającą dodatkową objętość ścieków dostarczaną z pobliskiej strefy. W drugim oszacowano końcową przepustowość równą $40000 \mathrm{~m}^{3} \cdot \mathrm{d}^{-1}$. W odniesieniu do oczyszczalni w Souk-Ahras testowano trzy scenariusze. W pierwszym rozpatrywano wpływ zwiększonej prędkości przepływu, w efekcie uzyskano 37-procentowe zmniejszenie produkcji osadu. Drugi scenariusz dotyczył zarządzania bilansem masy podłoża i biomasy. Trzeci z kolej polegał na ocenie docelowej przepustowości ścieków szacowanej na $60000 \mathrm{~m}^{3} \cdot \mathrm{d}^{-1}$.

Słowa kluczowe: Algieria, model ASMI, osad czynny, symulacja, ścieki 